DOI: $10.15193 /$ zntj/2020/123/338

\author{
WIESŁAW PRZYBYLSKI, DANUTA JAWORSKA, \\ KATARZYNA KAJAK-SIEMASZKO, PIOTR SAŁEK, MATEUSZ LUBAŃSKI
}

\title{
AN ASSESSMENT OF MEAT PRODUCTS WITH ADDED SELECTED BIOACTIVE SUBSTANCES
}

\begin{abstract}
Su m m a r y
Implementation of bioactive antioxidant compounds into the product can enhance the product quality and extend the shelf-life of meat and meat products. The aim of the study was to evaluate the effect of fish oil, lyophilisate of tomato concentrate and thyme extract additives on the oxidation stability, colour parameters and sensory quality of the meat product during its storage. This study was conducted on a model meat product in the form of meatballs made from minced: chicken breast muscles, turkey drumstick muscles, pork meat, with addition of eggs, wheat bread, salt, black pepper and herbal pepper. After heat treatment, the samples were cooled and were stored under vacuum at $4{ }^{\circ} \mathrm{C}$ for 14 days. It was shown that addition of $2 \%$ freeze-dried tomato concentrate to meatballs resulted in cooking yield increase during heat treatment, decrease of $\mathrm{pH}$ and changes in colour parameters as well as stabilization of colour during storage. The addition of tomato concentrate also improved the sensory quality and also influenced the maintenance of the overall quality during the initial storage period. The addition of $4 \%$ thyme extract to meatballs stopped oxidative changes and did not significantly affect the technological and sensory quality. Meatballs with the addition of cod liver oil and thyme extract were characterized by the highest overall quality after heat treatment. Based on sensory evaluation and oxidative status, meatballs can be stored for up to 7 days.
\end{abstract}

Key words: poultry meat, omega-3 fatty acids, thyme, tomatoes, sensory quality, oxidation

\section{Introduction}

Nowadays there is greater interest in foods that contain bioactive or functional components derived from natural sources like fruits, vegetables, herbs and spices which give additional benefits to their health status [20]. An important source of bioactive antioxidant compounds that prevent reactions of oxidation and extend the shelf-life

Prof. dr hab. W. Przybylski, dr hab. D. Jaworska, dr inż. K. Kajak-Siemaszko, dr inż. P. Sałek, inż. M. Lubański, Katedra Technologii Gastronomicznej i Higieny Żywności, Instytut Nauk o Żywieniu Człowieka, Szkoła Główna Gospodarstwa Wiejskiego w Warszawie, ul. Nowoursynowska 159 C, 02-776 Warszawa.Kontakt: wieslaw_przybylski@sggw.pl 
of meat and meat products are essential oils. The addition of these natural compounds into the product can enhance the product quality [20]. Besides positive oxidation inhibition also other product attributes should be considered, for example the colour and sensory properties can be negatively affected and in consequence worsen the acceptability of the final product [19].

Omega-3 acids are a frequent addition in functional foods due to their healthpromoting properties and very common deficiency in the human diet. Due to their presence mainly in fish oil, they bring upon a specific taste and aroma which is not accepted by most consumers. Therefore, it is necessary to introduce additives that inhibit these adverse changes. In turn, lycopene is considered to be the carotenoid which has the strongest antioxidative properties of all carotenoids. It is present mainly in tomatoes and their preserves [28]. In many studies tomato powder, tomato paste and tomato pomace were added with positive results to various meat products such as frankfurters [10, 25], hamburgers [12], mortadella [8]. Whereas thyme possesses various beneficial effects, e.g. antiseptic, carminative, antimicrobial and antioxidative properties [2] and its essential oil was added to minced beef meat by Zengin and Baysal [31].

Based on the mentioned properties of the selected additives, the aim of the study was to evaluate the influence of fish oil, lyophilisate of tomato concentrate or thyme extract additives on the oxidation stability, colour parameters and sensory quality during storage of poultry meat products.

\section{Material and methods}

The presented study was conducted on a model product in the form of meatballs. The raw materials for the production of meatballs included chicken breast muscles, turkey drumstick muscles, pork chops, eggs, wheat bread, salt, black pepper and herbal pepper. The characteristics of the raw material composition of tested samples before heat treatment is shown in Tab. 1.

Table 1. Characteristics of the composition of meat raw material before heat treatment Tabela 1. Charakterystyka składu surowca mięsnego przed obróbką cieplną

\begin{tabular}{||l|c|c|c|c||}
\hline \multicolumn{1}{|c|}{ Type of meat / Rodzaj mięsa } & $\mathrm{pH}$ & $\mathrm{L}^{*}$ & $\mathrm{a}^{*}$ & $\mathrm{~b}^{*}$ \\
\hline $\begin{array}{l}\text { Turkey drumstick meat } \\
\text { Mięso z podudzia indyka }\end{array}$ & 6.42 & 45.60 & 8.87 & 12.43 \\
\hline $\begin{array}{l}\text { Pork meat } \\
\text { Mięso wieprzowe }\end{array}$ & 5.99 & 72.86 & 1.85 & 10.73 \\
\hline $\begin{array}{l}\text { Chicken breast meat } \\
\text { Mięso z piersi kurcząt }\end{array}$ & 5.99 & 47.10 & -1.43 & 10.64 \\
\hline
\end{tabular}


All products were bought in the retail trade network. Meat (68\% chicken breast, $23 \%$ turkey drumstick and pork dewlap $-9 \%$ ) was minced on a grid with a diameter of $4 \mathrm{~mm}$. The obtained mass was divided into 5 equal parts, of which one was the control sample, to the four others $1 \%$ of cod liver oil, $4 \%$ of thyme extract, and $2 \%$ of freeze-dried tomato concentrate was added as shown in Tab. 2. For the purpose of the study Möller's cod liver oil (Orkla Health AS, Norway), Kamis brand thyme (McCormick Polska S.A., Polska) and freeze-dried tomato concentrate (Elena, Polska) were purchased at a supermarket in Warsaw and via the Internet.

Table 2. Characteristics of the quantity of variable additives: cod liver oil, thyme extract and freezedried tomato concentrate added to the meatballs

Tabela 2. Charakterystyka ilości zmiennych dodatków: tranu, ekstraktu tymianku i liofilizatu koncentratu pomidorowego wprowadzonych do pulpetów

\begin{tabular}{|l|c|c|c|c|c||}
\hline \multirow{2}{*}{\multicolumn{1}{|c|}{ Additives / Dodatki [\%] }} & \multicolumn{5}{c|}{ Samples / Próby } \\
\cline { 2 - 6 } & $\mathrm{A}$ & $\mathrm{B}$ & $\mathrm{C}$ & $\mathrm{D}$ & $\mathrm{E}$ \\
\hline Cod liver oil / Tran & - & 1.0 & 1.0 & 1.0 & 1.0 \\
\hline Thyme extract / Ekstrakt tymianku & - & - & 4.0 & - & 4.0 \\
\hline $\begin{array}{l}\text { Freeze-dried tomato concentrate } \\
\text { Liofilizat koncentratu pomidorowego }\end{array}$ & - & - & - & 2.0 & 2.0 \\
\hline
\end{tabular}

Explanatory notes / Objaśnienia:

A - control sample (without additives) / próba kontrolna (bez dodatków); sample with addition of / próba z dodatkiem: B - cod liver oil / tranu, C - cod liver oil and thyme extract / tranu i ekstraktu tymianku, D cod liver oil and tomato concentrate lyophilizate / tranu i liofilizatu koncentratu pomidorowego, E - cod liver oil, thyme extract and tomato concentrate lyophilizate / tranu, ekstraktu tymianku i liofilizatu koncentratu pomidorowego.

The thyme extract was obtained by pouring $150 \mathrm{ml}$ of water at $50{ }^{\circ} \mathrm{C}$ to $12 \mathrm{~g}$ of dried thyme. The lyophilized tomato concentrate was added in the form of the paste. The $40 \mathrm{~g}$ of lyophilisate was dissolved in the ratio 1: 1 with water.

From the mass meatballs with a diameter of about $5 \mathrm{~cm}$ were formed, heated in water with $0.8 \% \mathrm{NaCl}$ for about 3 min to reach a temperature of $78{ }^{\circ} \mathrm{C}$ in the geometrical center of the ball. After heat treatment, the samples were cooled to temperature 24 $\pm 2{ }^{\circ} \mathrm{C}$ and weighed. The samples were stored under vacuum at $4{ }^{\circ} \mathrm{C}$ for 14 days.

The cooking yield during the heat treatment process was determined by weighing the meatballs before and after heat treatment. The yield is expressed as a percentage of the mass before thermal treatment based on the formula:

$$
\mathrm{W}[\%]=(\mathrm{mg} / \mathrm{ms}) \times 100
$$

$\mathrm{W}$ - cooking yield, ms - mass before thermal treatment, mg - mass after thermal treatment. 
Meat colour was measured before and after heat treatment, and after 7 and 14 days of storage according to the CIE LAB (L*a*b*) system using a CM-2300d Konica Minolta meter with a D65 light source (Konica Minolta, Inc., Japan). Each sample of meat was evaluated in 3 replications.

The $\mathrm{pH}$ measurement was carried out before and immediately after the heat treatment, and after 7 and 14 days of storage with the WTW SET pH-meter 303i (Weilheim, Germany) with special electrodes (SenTix ${ }^{\circledR}$ SP number 103645) enabling $\mathrm{pH}$ measurement directly in meat.

The level of lipid oxidation during storage were estimated with the use of the TBARS method - determination of malondialdehyde (MDA) presence as described by Shahidi [27]. Two grams of minced meat samples were mixed with $5 \mathrm{ml} 10 \%$ trichloroacetic acid (TCA). Next $5 \mathrm{ml}$ 0,02 M 2-thiobarbituric acid (TBA) solution was added and mixed. Afterwards, samples were centrifuged at $4000 \mathrm{rpm}$ for $10 \mathrm{~min}$ and supernatants were filtered through quantitative paper to glass tubes. The tubes were covered in plastic foil and put in a boiling water bath $\left(98^{\circ} \mathrm{C}\right)$ for $35 \mathrm{~min}$ to develop the colour. After incubation the tubes were cooled immediately in cold water and the absorbance was measured by spectrophotometer GENESYS ${ }^{\mathrm{TM}} 20$ (Thermo Fisher Scientific, USA) at $532 \mathrm{~nm}$. The results were expressed as content of malondialdehyde (MDA) in meat $[\mathrm{mg} / \mathrm{kg}]$. Each sample of meat was evaluated in duplicate. The level of lipid oxidation was measured on the day of production and after 14 days of storage.

A semi-consumer evaluation was carried out within $2 \mathrm{~h}$ after the production process on a group of 40 consumers. An unstructured, linear scale $(100 \mathrm{~mm})$ converted to numerical values ( 0 - 10 conventional units - c.u.) was used. The marks of anchors of the hedonic test were acceptability (not acceptable - very acceptable) with regard to the colour, aroma, consistency and palatability of each sample. The evaluation conditions and the method of samples preparation were determined in accordance to Baryłko-Pikielna and Matuszewska [3].

For susceptibility to sensory changes of meatballs during storage the Quantitative Descriptive Analysis method (QDA) [14] was applied; an unstructured, linear scale $(100 \mathrm{~mm})$ converted to numerical values (0 - 10 c.u.) was used. Descriptors were chosen and defined during a panel discussion and then verified in a preliminary session. Finally, 12 sensory attributes were measured to quantify the quality of the tested products; 4 odour attributes (meat, sour, fatty, other), 2 attributes of colour, 1 texture attribute and 4 attributes of flavour (meat, sour, fatty, other) and salty taste. The marks of anchors of the tested attributes for most of them were: no intensity - high intensity, for juiciness: dry - juicy, for tone of colour: dark beige - light beige, homogeneity of colour: heterogeneous - homogeneous. On the basis of the above-mentioned quality characteristics, the assessing sensory panel indicated an overall sensory quality (low - very high) for each sample on a separate scale. A trained and experienced 9-person as- 
sessing panel with 5 - 15 years of sensory evaluation practice participated in the evaluation [15]. All of them had good command of sensory methodology and were familiar with the sensory quality of meat and meat products. Within $2 \mathrm{~h}$ after cooking the meat samples were tested at temperature $24 \pm 2{ }^{\circ} \mathrm{C}$.

The same sample preparation in both sensory tests took place. The meat samples were cut into portions of equal size, weighed (around $15 \mathrm{~g}-1$ ball cut in two equal pieces) and placed in plastic, odourless, disposable boxes covered with lids. The assessment was conducted in room with daylight. The assessment and condition mode were determined in accordance with the sensory rules. The sensory evaluation was carried out after the heat treatment of the meatballs, and after 7 and 14 days of storage.

The obtained results were analyzed using Excel and Statistica 10.0 PL. The effect of additing cod liver oil, thyme extract and freeze-dried tomato concentrate and the storage time on the physico-chemical parameters and sensory quality of poultry meatballs were estimated using a two-factor analysis of variance. The NIR test was used to determine the statistical significance of differences between means. In the case of QDA sensory data the method of Principal Component Analysis (PCA) was applied.

\section{Results and discussion}

\section{Quality of meatballs after preparation}

Meatballs with the addition of freeze-dried tomato concentrate were characterized by higher cooking yield in heat treatment. The cooking yield increased by about $4 \%$ in comparison to the control sample (Tab. 3). This is most likely the result of the hydra-

Table 3. Cooking yield $[n=3]$ and sensory acceptability of the tested samples $[n=40]$

Tabela 3. Wydajność $[n=3]$ oraz akceptowalność sensoryczna testowanych prób [n=40]

\begin{tabular}{||l|c|c|c|c|c||}
\hline \multirow{2}{*}{\multicolumn{1}{|c|}{ Features / Cechy }} & \multicolumn{5}{|c||}{ Samples / Próby } \\
\cline { 2 - 6 } & A & B & C & D & E \\
\hline $\begin{array}{l}\text { Cooking yield } \\
\text { Wydajność [\%] }\end{array}$ & 71.60 & 71.45 & 71.70 & 74.90 & 75.25 \\
\hline Aroma / Zapach [c.u. / j.u.] & $3.97^{\mathrm{a}}$ & $4.01^{\mathrm{ac}}$ & $4.06^{\mathrm{a}}$ & $5.16^{\mathrm{bc}}$ & $5.48^{\mathrm{b}}$ \\
\hline Colour / Barwa [c.u. / j.u.] & $3.30^{\mathrm{a}}$ & $3.46^{\mathrm{a}}$ & $3.80^{\mathrm{a}}$ & $5.10^{\mathrm{b}}$ & $5.37^{\mathrm{b}}$ \\
\hline $\begin{array}{l}\text { Consistency } \\
\text { Konsystencja [c.u. / j.u.] }\end{array}$ & $4.25^{\mathrm{a}}$ & $5.03^{\mathrm{ac}}$ & $5.26^{\mathrm{ac}}$ & $5.72^{\mathrm{bc}}$ & $5.64^{\mathrm{bc}}$ \\
\hline $\begin{array}{l}\text { Palatability } \\
\text { Smakowitość [c.u. / j.u.] }\end{array}$ & $4.07^{\mathrm{a}}$ & $4.84^{\mathrm{ab}}$ & $4.87^{\mathrm{ab}}$ & $5.66^{\mathrm{b}}$ & $5.69^{\mathrm{b}}$ \\
\hline
\end{tabular}

Explanatory notes / Objaśnienia:

a, b, c - mean values denoted by different letters differ statistically significantly $(p<0.05) /$ wartości średnie oznaczone różnymi literami różną się statystycznie istotnie $(\mathrm{p}<0,05)$. Other explanatory notes as in Tab. 2. / Pozostałe objaśnienia jak pod tab. 2. 
tion of the lyophilisate during the heat treatment in the water environment. Other research of Savadkoohi et al. [25] indicated that tomato pomace-added sausages had higher water holding capacity compared to that of commercial samples.

Addition of cod liver oil (B) caused a consistency improvement probably due to the increase in the juiciness. In samples with the addition of thyme extract and tomato lyophilisate $(\mathrm{C}, \mathrm{D}, \mathrm{E})$ there was an increase in sensory acceptability by about one unit to $5.26 \div 5.72$ on a 0 - 10 scale compared to the control sample (Tab. 3). Cáceres et al. [5] showed deterioration of mortadella samples under the influence of added fish oil. Przybysz et al. [23] confirmed, that an additive of $1 \%$ in relation to the total weight of the product, of EPA and DHA for food does not affect acceptability and the flavour and aroma of fish oil was not perceptible. In the presented research, the poultry meatballs with the addition of cod liver oil were not assessed well by consumers.

In studies by García et al. [12], the most desirable level of addition of lycopene to beef hamburgers was an additive of $4.5 \%$ in relation to the weight of the product. Higher levels negatively affected the overall quality of hamburgers. In the presented research, the addition of freeze-dried tomato concentrate positively influenced the characteristics of the meatball odour, colour, consistency, and acceptability. However, its combination with thyme extract improved only the odour and colour, a slight improvement was observed in the palatability. According to Skiepko et al. [28], lycopene positively influenced the colour of meat products. Hayes et al. [13] also observed a positive effect of using lycopene in meat products in assessing colour and overall quality. In the presented research, slight deterioration in the consistency of the meatballs was observed in the case of a combination of thyme extract and tomato lyophilisate.

\section{Quality of meatballs during storage - technological quality}

A significant influence of the additives used in the technological process on the $\mathrm{pH}$ value and the instrument's colour parameters were found (Tab. 4). The addition of freeze-dried tomato concentrate significantly decreased the $\mathrm{pH}$ of the meatballs; especially in the final storage period (Fig. 1). The observed effect of tomato concentrate on lowering the $\mathrm{pH}$ confirmed the results of Deda et al. [7] and Eyiler and Oztan [10] in case of frankfurters. Lowering the $\mathrm{pH}$ most probably resulted from the presence of relatively high amounts of vitamin $\mathrm{C}$ and organic acids in tomato concentrate, as demonstrated in the studies by Bracławska-Zamajtys et al. [4]. In their research, the authors used the same product that was used in author's own experiment.

The addition of freeze-dried tomato concentrate also significantly influenced the colour parameters of the produced meatballs. Samples were characterized by lower brightness of colour and at the same time greater stability of colour brightness and were more red and more yellow (Tab. 4). In the study published by Hayes et al. [13] 
added tomato pomace reduced the $\mathrm{pH}$ and increased the colour parameters $\mathrm{a}^{*}$ and $\mathrm{b}^{*}$ of both the raw and cooked luncheon roll product. Bracławska-Zamajtys et al. [4] showed that the increase of the amount of added freeze-dried tomato concentrate significantly lowered the brightness of the colour and led to an increase in the color parameter a* and $b^{*}$. In turn Savadkoohi et al. [25] claimed that redness ( $\left.a^{*}\right)$ of beef frankfurter samples was significantly affected by tomato pomace level (greater than $3 \%$ ), while there were no significant differences in the values of lightness $\left(\mathrm{L}^{*}\right)$ and yellowness $\left(b^{*}\right)$. Yellowness increase may be due to the accumulation of Schiff pigments (lipofuschin) from lipid to protein complexes as a result of oxidative stress [6]. Eyiler and Oztan [10] state that tomato powder acted as a colouring agent in frankfurters and caused an increase at the $a^{*}$ value of the samples. Meanwhile the lightness $\left(\mathrm{L}^{*}\right)$ of the samples decreased.

Table 4. The results of measurement of colour parameters of meatballs

Tabela 4. Wyniki pomiaru parametrów barwy pulpetów mięsnych

\begin{tabular}{||c|c|c|c|c|c|c||}
\hline \multirow{2}{*}{$\begin{array}{c}\text { Features } \\
\text { Wyróżniki }\end{array}$} & \multirow{2}{*}{$\begin{array}{c}\text { Days of storage } \\
\text { Dni przechowywania }\end{array}$} & \multicolumn{5}{|c||}{ Samples / Próby } \\
\cline { 3 - 7 } & 1 & $\mathrm{~A}$ & $\mathrm{~B}$ & $\mathrm{C}$ & $\mathrm{D}$ & $\mathrm{E}$ \\
\hline \multirow{3}{*}{$\mathrm{L}^{*}$} & 14 & $72.56^{\mathrm{a}}$ & $72.58^{\mathrm{a}}$ & $67.71^{\mathrm{b}}$ & $65.05^{\mathrm{c}}$ & $64.95^{\mathrm{c}}$ \\
\cline { 2 - 7 } & 1 & $66.97^{\mathrm{a}}$ & $68.59^{\mathrm{ab}}$ & $69.32^{\mathrm{b}}$ & $62.36^{\mathrm{c}}$ & $63.81^{\mathrm{c}}$ \\
\hline \multirow{2}{*}{$\mathrm{a}^{*}$} & 14 & $2.06^{\mathrm{a}}$ & $1.95^{\mathrm{a}}$ & $2.29^{\mathrm{a}}$ & $8.45^{\mathrm{b}}$ & $8.69^{\mathrm{b}}$ \\
\cline { 2 - 7 } & 1 & $2.61^{\mathrm{a}}$ & $1.89^{\mathrm{a}}$ & $2.99^{\mathrm{a}}$ & $10.35^{\mathrm{b}}$ & $11.46^{\mathrm{b}}$ \\
\hline \multirow{2}{*}{$\mathrm{b}^{*}$} & 14 & $15.76^{\mathrm{a}}$ & $16.09^{\mathrm{a}}$ & $16.33^{\mathrm{a}}$ & $21.46^{\mathrm{b}}$ & $21.97^{\mathrm{b}}$ \\
\cline { 2 - 7 } & $20.39^{\mathrm{a}}$ & $18.90^{\mathrm{ab}}$ & $17.76^{\mathrm{b}}$ & $26.55^{\mathrm{c}}$ & $27.98^{\mathrm{c}}$ \\
\hline
\end{tabular}

Explanatory notes as in Tab. 3. / Objaśnienia jak pod tab. 3.

It seems that tomato pomace can be used in sausage formulation to improve the organoleptic and technological quality of the sausage. Many studies have shown that the coloring properties of lycopene found in tomatoes and tomato concentrates can be used in the production of sausages, hamburgers, mortadella, fermented sausages and raw cured meats $[7,8,12,13,28]$. These studies demonstrated that the addition of processed tomato products improved colour, nutritional properties and increased colour stability during storage, as well as limiting oxidative processes. According to Szajdek and Borowska [29], lycopene found in tomatoes has strong antioxidant properties related to the presence of 11 conjugated double bonds in the molecule.

Zengin and Baysal [31] stated that there was no significant difference among $\mathrm{a}^{*}$ values of control and samples with thyme essential oils throughout the storage period. There was also no significant difference between $b^{*}$ values of treated samples. But $b^{*}$ values showed a significant alteration up to 9 days in $4{ }^{\circ} \mathrm{C}$. The colour parameters - 


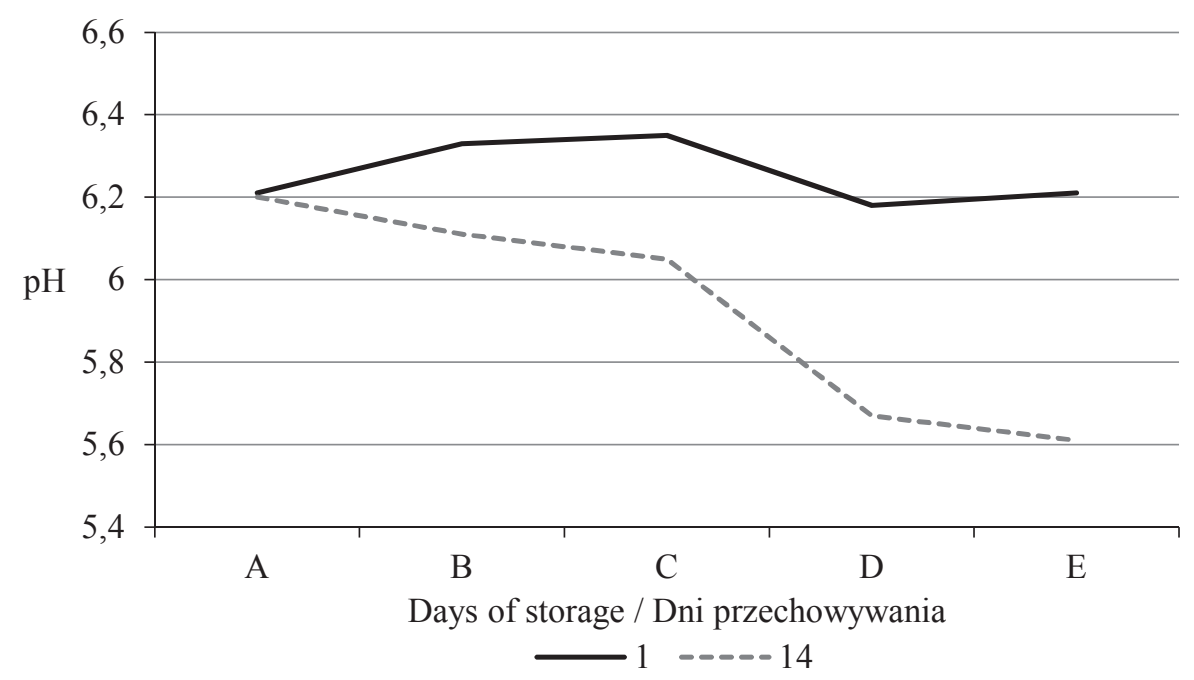

Explanatory note / Objaśnienie:

A - E - meanings of symbols as in Tab. 2 / objaśnienia symboli jak pod tab. 2.

Fig. 1. The $\mathrm{pH}$-value of meatballs after 1 and 14 days of storage

Rys. 1. Wartość pH pulpetów mięsnych po 1 i 14 dniach przechowywania

lightness, redness and yellowness were not significantly affected by the addition of thyme essential oils, when compared with control This suggests that changes in colour parameters do not cause significant impact on sensory acceptability by consumers.

The use of bioactive additives to improve the nutritional value of meat products has already been the subject of numerous studies $[4,9,22]$. In author's own research, enrichment of poultry meatballs with polyunsaturated long-chain fatty acids derived from fish oil and the addition of thyme extract and freeze-dried tomato concentrate to limit oxidative changes and improve the sensory quality features were used. According to Piotrowska et al. [22], the most common way to increase the content of $n-3$ polyunsaturated fatty acids (PUFA) in meat is the use of flaxseed, linseed oil or fish oil in feed. However, improving the nutritional value of meat and meat products enriched with PUFA may lead to deterioration of the sensory quality and durability of the obtained product. This is due to the susceptibility of PUFA to oxidation processes $[9,22]$. Therefore, it is necessary to use additives that inhibit oxidation processes and improve sensory quality by limiting the taste and smell of fish and rancid. Currently, plantbased additives with antioxidant properties are used, such as herbs and spice extracts [29]. One of the additives recently used for this purpose is lycopene or tomato concentrate $[4,28]$. 
Quality of meatballs during storage - lipid oxidation

In the case of samples with added cod liver, the durability of the product was reduced. The level of lipid oxidation transformation increased with storage time (Fig. 2). In the studies of Domiszewski et al. [9], significant changes were observed in pork meatballs with the addition of fish oil after 3 days of storage under refrigeration conditions. The level of oxidative changes was unacceptable. In studies concerning poultry frankfurter [16], fermented sausage [21] and pork sausage [30], shorter storage time of products with the addition of fish oil was also demonstrated. To minimize the negative effects of oxidative changes, antioxidant substances are usually added. In author's own research, meatballs without any antioxidant additives (A and B) were less oxidatively stable than samples with antioxidants (Fig. 2). Addition of thyme extract and freezedried tomato concentrate (samples C, D and E) increased the products' oxidative stability. In author's own research, the best addition based on the level of TBARS in the meatballs was thyme extract (sample C).

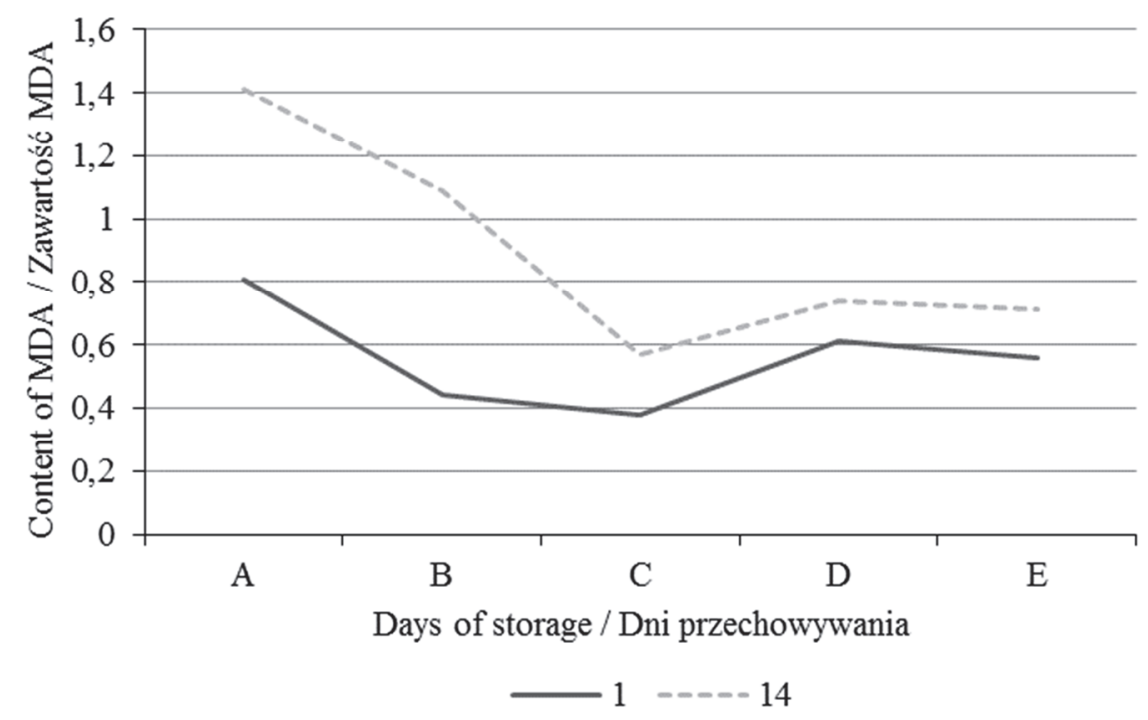

Explanatory note / Objaśnienie:

A - E - meanings of symbols as in Tab. 2 / objaśnienia symboli jak pod tab. 2.

Fig. 2. The results of TBARS evaluation (content of malondialdehyde - MDA) in meatballs after 1 and 14 days of storage

Rys. 2. Wyniki wskaźnika TBARS (zawartość malondialdehydu - MDA) w pulpetach mięsnych po 1 i 14 dniach przechowywania

Thyme essential oil has a great potential to be used in meat products due to its powerful antioxidant properties. Its effectiveness was tested in fresh chicken breast 
meat with added balm oil, extracted from the leaves of Melissa officinalis species, during 3 weeks of storage at $4{ }^{\circ} \mathrm{C}$ [11]. The obtained results showed that $0.5 \%$ of thyme essential oil is enough to reduce radical formation, decrease the lipid peroxidation, avoid the deterioration of sarcoplasmic proteins and decrease deterioration reactions and extend the shelf-life of the product [11]. Besides, the use of lower doses of thyme essential oil in fresh chicken sausage $(0.125 \%)$ also confirmed the decrease of lipid oxidation without affected proteolysis and sensory properties of sausages [26]. Zengin and Baysal [31] also confirmed the antioxidant properties of the addition of thyme oil to ground beef - their study results indicated that thyme essential oils retarded lipid oxidation during 9 days of storage at $4{ }^{\circ} \mathrm{C}$. Similar results were obtained by Karabagias et al. [17], in which thyme extract showed the best antioxidant properties among popular herbs.

The oxidation stability was also positively influenced by the addition of freezedried tomato concentrate (Fig. 2). In samples $\mathrm{C}, \mathrm{D}$ and $\mathrm{E}$ the MDA $/ \mathrm{kg}$ value ranged from 0.57 to 0.71. In studies by Skiepko et al. [28], Deda et al. [7], Hayes et al. [13], Doménech-Asensi et al. [8], the addition of lycopene in meat products reduced lipid oxidation. Sánchez-Escalante et al. [24] confirmed that lycopene prolongs the durability of beef patties. Tomato powder has also been reported to reduce TBARS values in pork sausages and effectively retarded lipid oxidation until the end of storage day [18]. In this study all samples did not exceed $1 \mathrm{mg} \mathrm{MDA} / \mathrm{kg}$ sample content during the 28 days of storage. Similar results were reported by Eyiler and Oztan [10] in frankfurters with 2 and $4 \%$ of sun-dried tomato powder during 1 month of storage under $4{ }^{\circ} \mathrm{C}$. On the contrary Andrés et al. [1] stated that pomace extract addition did not protect meat against lipid oxidation, since no significant differences were found between treatments (control, extract obtained by using ethyl acetate and ethanol treatment).

In the sample with the addition of thyme (C), the TBARS decreased by about 3 times, while in the samples with the addition of tomato lyophilisate (D, E) about 4-fold decrease in TBARS in comparison to the control sample and the addition of cod liver oil (A, B) was observed.

\section{Quality of meatballs during storage - sensory analysis}

The scale and type of differences and similarities of the tested samples based on QDA data are shown in the PCA graphic projection (Fig. 3). The first two principal components explain $82.12 \%$ of the total variability of the sensory quality of the samples. Attributes of meat odour and meat flavour are positively associated with overall quality. Attributes of fatty taste, fatty odour, sour odour, other odour, other flavour as well as salty flavour were directed in the opposite direction of the overall quality vector, meaning that the latter attributes have negative association with the overall quality of the investigated samples. The long vector of tone of colour, juiciness and sour fla- 
vour demonstrates that there is high variability in these attributes. The samples with tomato lyophilisate (D and $\mathrm{E}$ ) directly after production process and after 7 days of storage are related to meat odour and overall quality. However, after 14 days of storage they are related to sour flavour. As for the other samples (A, B and C) directly after production process there are close to each other, along with storage time the samples move towards fatty flavour and fatty odour as well as other odour.

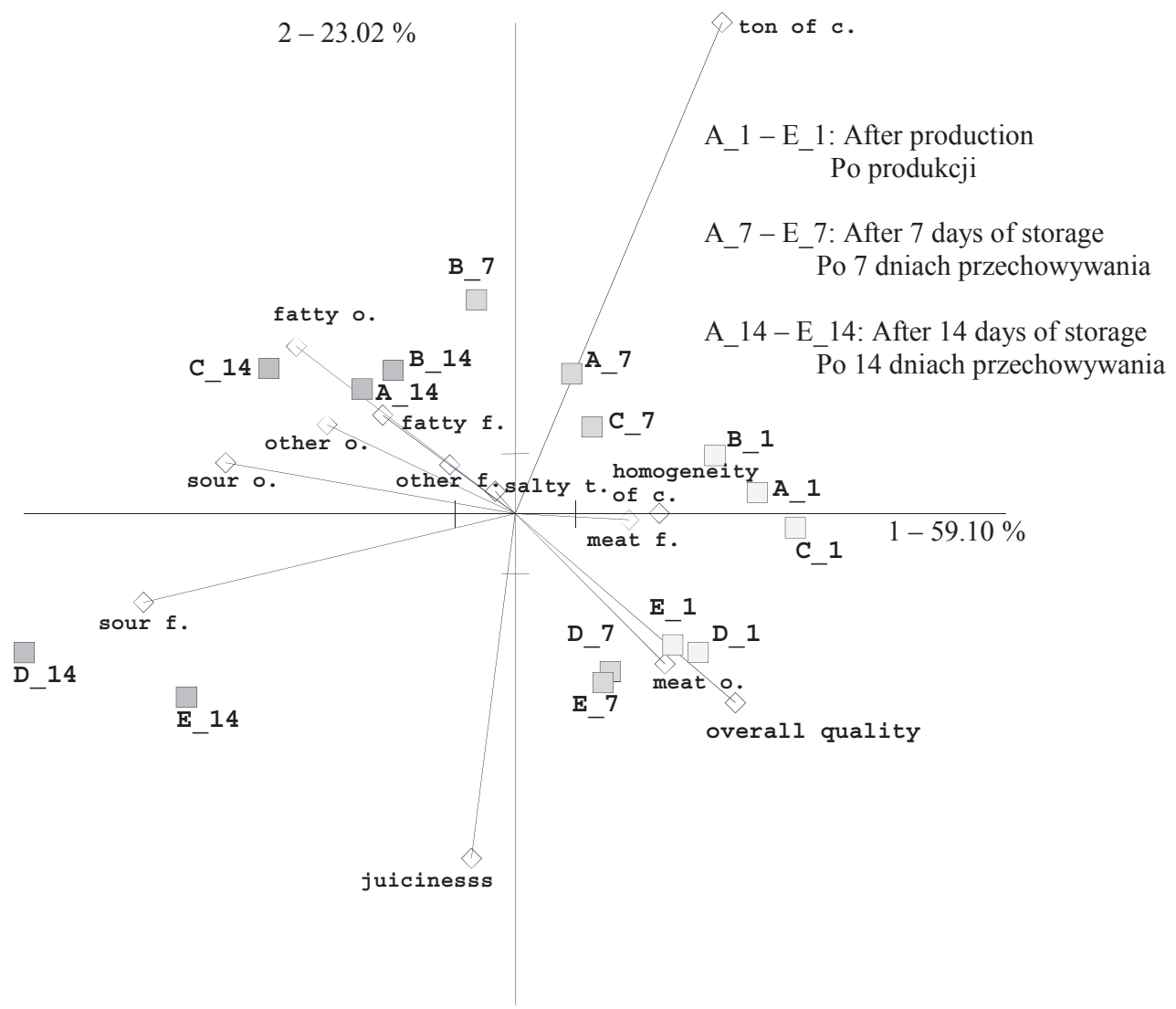

Explanatory notes / Objaśnienia:

A - E - meanings of symbols as in Tab. 2 / objaśnienia symboli jak pod tab. 2; o. - odour / zapach, f. - flavour / smakowitość, c. - colour / barwa, t. - taste / smak.

Fig. 3. The results of Principal Component Analysis (PCA) of sensory attributes of meatballs obtained by QDA method

Rys. 3. Wyniki analizy głównych składowych (PCA) wyróżników sensorycznych pulpetów mięsnych, otrzymanych metodą QDA

Deda et al. [7] in their studies claimed that using tomato purée as an additive to meat products is only suitable for fresh products and products stored less than 14 days. 
During longer storage changes were not accepted by consumers. In author's own studies 14-day storage significantly lowered the sensory assessment of the meatballs. This was most likely caused by acidification of the samples. In the case of shorter storage antioxidant additives positively influenced the overall quality and juiciness of products.

The reduced colour tone for samples D and E was caused by the addition of lyophilized tomato, which changed the colour tone from light-beige to dark-beige. According to Skiepko et al. [28], lycopene is a commonly used dye in meat products due to its color-improving properties.

\section{Conclusions}

1. It was shown that the additives (cod liver oil, thyme extract and freeze-dried tomato concentrate) significantly affected the physicochemical characteristics and sensory quality of poultry meatballs.

2. Addition of freeze-dried tomato concentrate to meatballs resulted in increased cooking yield in heat treatment, decreased $\mathrm{pH}$ and changes in colour parameters (reduced brightness, increased intensity of $\mathrm{a}^{*}$ and $\mathrm{b}^{*}$ parameter) and their stabilization during storage. It also improved the sensory quality and influenced the maintenance of the products' overall quality during the initial storage period.

3. Addition of thyme extract to the meatballs significantly reduced oxidative changes and at the same time did not significantly affect the colour parameters, $\mathrm{pH}$ and sensory quality. Meatballs with the addition of cod liver oil and thyme extract were characterized by the highest overall quality after heat treatment.

4. Based on their sensory quality and oxidative status it was shown that only 7 days of storage of meatballs was practicable.

\section{References}

[1] Andrés A.I., Petrón M.J., Delgado-Adámez J., López M., Timón M.L.: Effect of tomato pomace extracts on the shelf-life of modified atmosphere-packaged lamb meat. J. Food Process. Preserv., 2017, 41 (4), \#e13018.

[2] Baranauskiene R., Venskutonis P.R., Viskelis P., Dambrauskiene E.: Influence of nitrogen fertilizers on the yield and composition of thyme (Thymus vulgaris). J. Agric. Food Chem., 2003, 51, 77517758.

[3] Baryłko-Pikielna N., Matuszewska I.: Sensoryczne badania żywności. Podstawy. Metody. Zastosowania. Wyd. II. Wyd. Nauk. PTTŻ, Kraków 2014.

[4] Bracławska-Zamajtys A., Sałek P., Jaworska D., Hallman E., Przybylski W.: Charakterystyka jakości produktów mięsnych z dodatkiem liofilizowanych ekstraktów pomidorowych. XLVII Dni Przemysłu Mięsnego oraz Sympozjum Naukowo-Techniczne pt. „Postęp w technologii mięsa. Nauka w Praktyce”, Instytut Biotechnologii Przemysłu Rolno-Spożywczego, Warszawa, 2017. 
[5] Cáceres E., Garcia M.L., Selgas M.D.: Effect of pre-emulsified fish oil - as source of PUFA $n$-3 - on mictrostructure and sensory properties of mortadella, a Spanish bologna-type sausage. Meat Sci., 2008, 80, 183-193.

[6] Chelh I., Gatellier P., Santé-Lhoutellier V.: Characterization of fluorescent Schiff bases formed during oxidation of pig myofibrils. Meat Sci., 2007, 76, 210-215.

[7] Deda M.S., Bloukas J.G., Fista G.A.: Effect of tomato paste and nitrive level on processing and quality characteristics of frankfurters. Meat Sci., 2007, 76, 501-508.

[8] Doménech-Asensi G., García-Alonso F.J., Martínez E., Santaella M., Martín-Pozuelo G., Bravo S., Periago M.J.: Effect of the addition of tomato paste on the nutritional and sensory properties of mortadela. Meat Sci., 2013, 93, 213-219.

[9] Domiszewski Z., Łaszczak A., Kosińska M., Grudka A.: Wpływ dodatku oleju rybiego, sposobu gotowania i czasu przechowywania na jakość lipidów w pulpetach z mięsa wieprzowego. Folia Pomeranae Universitatis Technologiae Stetinensis seria Agricultura, Alimentaria, Piscaria et Zootechnica, 2013, 307(28), 23-24.

[10] Eyiler E., Oztan A.: Production of frankfurters with tomato powder as a natural additive. LWT Food Sci. Technol., 2011, 44, 307-311.

[11] Fratianni F., de Martino L., Melone A., de Feo V., Coppola R., Nazzaro F.: Preservation of chicken breast meat treated with thyme and balm essential oils. J. Food Sci., 2010, 75(8), M528-M535.

[12] García M.L., Calvo M.M., Selgas M.D.: Beef hamburgers enriched in lycopene using dry tomato peel as an ingredient. Meat Sci., 2009, 83, 45-49.

[13] Hayes J.E., Canonico I., Allen P.: Effects of organic tomato pulp powder and nitrite level on the physicochemical, textural and sensory properties of pork luncheon roll. Meat Sci., 2013, 95, 755-762.

[14] ISO 13299:2016. Sensory analysis. Methodology. General guidance for establishing a sensory profile.

[15] ISO 8586:2012. Sensory analysis. General guidelines for the selection, training and monitoring of selected assessors and expert sensory assessors.

[16] Jeun-Horng L., Youan-Hui L., Chun-Chin K.: Effect of dietary fish oil fatty acid composition lipid oxidation and sensory property of chicken frankfurters during storage. Meat Sci., 2002, 60, 161-167.

[17] Karabagias I., Badeka A., Kontominas M.G.: Shelf life extension of lamb meat using thyme or oregano essential oils and modified atmosphere packaging. Meat Sci., 2011, 88, 109-116.

[18] Kim H.S., Chin K.B.: Antioxidant activity of tomato powders as affected by water solubility and application to the pork sausages. Korean J. Food Sci. An., 2013, 33, 170-180.

[19] Kumar Y., Yadav D.N., Ahmad T., Narsaiah K.: Recent trends in the use of natural antioxidants for meat and meat products. Compr. Rev. Food Sci. F., 2015, 14, 796-812.

[20] Pateiro M., Barba F.J., Domínguez R., Sant'Ana A.S., Khaneghah A.M., Gavahian M., Gómez B., Lorenzo J.M.: Essential oils as natural additives to prevent oxidation reactions in meat and meat products: A review. Food Res. Int., 2018, 113, 156-166.

[21] Pelser W.M., Linssen J.P.H., Legger A., Houben J.H.: Lipid oxiation in $n$-3 fatty acid enriched Dutch style fermented sausages. Meat Sci., 2007, 75, 1-11.

[22] Piotrowska A., Świąder K., Waszkiewicz-Robak B., Świderski F.: Możliwość uzyskania mięsa i przetworów z mięsa wieprzowego o podwyższonej zawartości wielonienasyconych kwasów tłuszczowych $n$-3. Żywność. Nauka. Technologia. Jakość, 2012, 5(84), 5-19.

[23] Przybysz M.A., Szterk A., Zawiślak M., Dłużewska E.: Wpływ procesu mikrokapsułkowania i dodatku przeciwutleniaczy na stabilność oleju rybnego. Żywność. Nauka. Technologia. Jakość, 2014, 2(93), 123-138.

[24] Sánchez-Escalante A., Torrescano G., Djenane D., Beltrán J.A., Roncalés P.: Stabilisation of colour and odour of beef patties by using lycopene-rich tomato and peppers as a source of antioxidants. J. Sci. Food Agric., 2003, 83, 187-194. 
[25] Savadkoohi S., Hoogenkamp H., Shamsi K., Farahnaky A.: Color, sensory and textural attributes of beef frankfurter, beef ham and meat-free sausage containing tomato pomace. Meat Sci., 2014, 97, 410-418.

[26] Sharma H., Mendiratta S.K., Agrawal R.K., Gurunathan K., Kumar S., Singh T.P.: Use of various essential oils as bio preservatives and their effect on the quality of vacuum packaged fresh chicken sausages under frozen conditions. LWT - Food Sci. Technol., 2017, 81, 118-127.

[27] Shahidi F.: The 2-tiobarbituric acid (TBA) methodology for the evaluation of warmed-over flavour and rancidity in meat products. $36^{\text {th }}$ ICoMST, Cuba, 1990, pp. 1008-1014.

[28] Skiepko N., Chwastowska-Siwicka I., Kondratowicz J.: Właściwości likopenu i jego wykorzystanie do produkcji żywności funkcjonalnej. Żywność. Nauka. Technologia. Jakość, 2015, 6(103), 20-32.

[29] Szajdek A., Borowska J.: Właściwości przeciwutleniające żywności pochodzenia roślinnego. Żywność. Nauka. Technologia. Jakość, 2004, 4(41) Supl., 5-28.

[30] Valencia I., O’Grady M.N., Ansorena D., Astiasarán I., Kerry J.P.: Enhancement of the nutritional status and quality of fresh pork sausages following the addition of linseed oil, fish oil and natural antioxidants. Meat Sci., 2008, 80, 1046-1054.

[31] Zengin H., Baysal A.H.: Antioxidant and antimicrobial activities of thyme and clove essential oils and application in minced beef. J. Food Process. Preserv., 2015, 39, 1261-1271.

\section{OCENA PRODUKTÓW MIĘSNYCH Z DODATKIEM WYBRANYCH SUBSTANCJI BIOAKTYWNYCH}

$$
\text { Streszczen i e }
$$

Dodatek bioaktywnych związków przeciwutleniających do produktów może podwyższyć ich jakość i wydłużyć okres przechowywania mięsa i produktów mięsnych. Celem pracy była ocena wpływu dodatku tranu, liofilizatu koncentratu pomidorowego i ekstraktu tymianku na stabilność oksydacyjną, parametry barwy i jakość sensoryczną produktu mięsnego podczas jego przechowywania. Badanie przeprowadzono na modelowym produkcie mięsnym $\mathrm{w}$ postaci pulpetów wykonanych $\mathrm{z}$ rozdrobnionego surowca pochodzącego z mięśni piersi kurcząt, mięśni podudzia z indyka, mięsa wieprzowego, z dodatkiem jaj, bułki tartej, soli, czarnego pieprzu, pieprzu ziołowego. Po obróbce cieplnej próbki chłodzono i przechowywano pod próżnią w temp. $4{ }^{\circ} \mathrm{C}$ przez 14 dni. Wykazano, że 2-procentowy dodatek liofilizowanego koncentratu pomidorowego do pulpetów mięsnych spowodował zwiększenie wydajności gotowania podczas obróbki cieplnej, obniżenie $\mathrm{pH}$ oraz zmiany parametrów barwy i stabilizację barwy podczas przechowywania. Dodatek koncentratu pomidorowego poprawił również jakość sensoryczną, a także wpłynął na utrzymanie ogólnej jakości podczas początkowego okresu przechowywania. Dodatek 4 \% ekstraktu z tymianku do pulpetów mięsnych spowodował zatrzymanie zmian oksydacyjnych i nie wpłynął znacząco na jakość technologiczną i sensoryczną. Pulpety z dodatkiem tranu i ekstraktu z tymianku charakteryzowały się najwyższą ogólną jakością po obróbce cieplnej. Na podstawie oceny sensorycznej i statusu oksydacyjnego możliwe jest przechowywanie pulpetów do 7 dni.

Słowa kluczowe: mięso drobiowe, kwasy omega-3, tymianek, pomidory, jakość sensoryczna, utlenianie 果

Numery ORCID:

Wiesław Przybylski - 0000-0003-4949-370X

Danuta Jaworska - 0000-0002-1242-5255

Katarzyna Kajak-Siemaszko - 0000-0003-0187-8125

Piotr Sałek - 0000-0001-8012-3593 